RESENHA

\title{
Neohegemonia americana ou multipolaridade? Pólos de poder e sistema internacional*
}

CRISTINA SOREANU PECEQUILO**

Desde o fim da Guerra Fria, os debates sobre o reordenamento do sistema internacional tem sido uma constante, trazendo diversos desafios para os Estados que se relacionam neste novo sistema e buscam estabelecer uma agenda positiva que responda a esta realidade e a seus dilemas internos. Assim, estamos diante de uma fase de reordenamento do poder mundial, na qual mais do que respostas, apresentam-se perguntas sobre os novos equilíbrios que se construirão no médio e longo prazo. Aprofundando estas reflexōes e oferecendo um panorama sobre o tema, surge como essencial a publicação do livro Neohegemonia Americana ou Multipolaridade? Pólos de Poder e Sistema Internacional, organizado por Paulo Vizentini e Marianne Wiesebron.

Editado pela Ed. UFRGS, consolidando sua tradição na área, o livro é composto por uma coletânea de artigos e pertence à Série Estudos InternacionaisNERINT/ILEA. Tais artigos originaram-se de Seminário realizado pelo Instituto Clingendale de Relaçôes Internacionais de Haia, e representam um esforço conjunto de debate sobre os pólos de poder do sistema, tentando responder à pergunta título: neohegemonia ou multipolaridade?

O livro inicia-se com uma avaliação de Immanuel Wallerstein sobre a neohegemonia, simbolizada na Doutrina Bush de caráter preventivo e seus impactos como a Guerra do Iraque no texto "A Doutrina Bush: um ensaio interpretativo". O fim da bipolaridade representou um ponto de inflexão e declínio para os EUA. A ascensão neoconservadora e suas políticas são prova deste refluxo, inexistindo alternativas a este modelo. Esta ausência é ressaltada por Paul Marie de La Gorce em "A União Européia face à unipolaridade e à multipolaridade". A despeito da integração, de iniciativas autônomas prévias como o gaullismo falta à Europa (e a suas naçoes) uma postura assertiva, questionando-se a capacidade deste eixo e, mesmo, o vigor do bloco ocidental.

\footnotetext{
* Resenha de VIZENTINI, Paulo e WIESEBRON, Marianne (orgs). Neohegemonia Americana ou Multipolaridade? Pólos de Poder e Sistema Internacional. Porto Alegre: Ed. UFRGS, 2006. ISBN 85-7025-900-X.

** Professora de Relaçôes Internacionais da Universidade Estadual Paulista - UNESP (Campus Marília), e pesquisadora associada do Núcleo de Estratégia e Relações Internacionais da Universidade Federal do Rio Grande do Sul - Nerint-UFRGS (crispece@gmail.com).
} 
Poder-se-ia argumentar que o futuro da ordem residiria em um novo referencial: países desenvolvidos do Oriente (Japão) e emergentes. Contudo, como indicam os demais textos, existem limites que dificultam tal projeção: vulnerabilidades sócio-econômicas, desconfianças mútuas e o peso do status quo. Todavia, potencialidades e o desejo de autonomia são uma realidade.

Analisando este viés, o artigo de Kurt Radtke "Leste Asiático em busca de segurança geopolítica (energética): conceitualização japonesa e chinesa em um mundo em globalização", aborda a evolução chinesa e japonesa. O autor ressalta a agenda global e regional das nações e seu relacionamento com os EUA. Segurança, energia, mercados e o equilíbrio de poder são debatidos. A próxima nação é a Rússia, analisada em dois artigos de Alexander Zhebit e André Gerrits: "Repensar a Rússia: uma proposta sobre o reposicionamento da Rússia nas relaçōes internacionais" e "Hegemonia americana e multipolaridade: o sistema internacional no século XXI". Os textos indicam a passagem de superpotência à emergente e o perfil da política externa pragmática de Putin frente aos EUA, Europa e OTAN, às regiōes da antiga URSS, aos emergentes e às organizações multilaterais, sem descartar o revisionismo.

Fechando o livro, artigos abordam o G3, Índia, Brasil e África do Sul. Em "Índia: os amargos frutos da ambição grandiosa", John Harris discute a política doméstica indiana, destacando criticamente sua trajetória global e regional: autonomia na década de 1960 com o MNAL, ambiguidade nos anos 1970/80 e 1990/2000, aproximação com os EUA dada a nuclearização do país, o que teria limitado estrategicamente o país. Paulo Vizentini, um dos organizadores (autor da Introdução, enquanto o Prefácio é de Wiesebron), em "O Brasil e a integração sul-americana: força e fragilidade de um gigante periférico" examina os desafios diplomáticos e de segurança do país, suas parcerias globais e a integração sulamericana. Completando, Greg Mills analisa em "Pólos à parte? África do Sul, Iraque e o debate unilateralismo-multipolaridade" os pontos de estrangulamento internos e a agenda da política externa da África do Sul.

Em sua diversidade, o livro destaca-se como uma contribuição significativa aos que desejem compreender um cenário em mudança, que oscila entre a uni e a multipolaridade, ajudando a pensar o papel do Brasil e demais Estados, sejam eles hegemônicos, desenvolvidos ou emergentes na construção desta nova ordem. 